\title{
PUSAT EDUKASI SAINS TUBUH DAN TEKNOLOGI
}

\author{
Yohanes Terzagi ${ }^{1)}$, Alvin Hadiwono ${ }^{2)}$ \\ 1) Program Studi S1 Arsitektur, Fakultas Teknik, Universitas Tarumanagara, yohanes.terzagi@gmail.com \\ 2) Program Studi S1 Arsitektur, Fakultas Teknik, Universitas Tarumanagara, alvinhadiwono@ymail.com
}

\begin{abstract}
Abstrak
Generasi millenial yang lahir pada era kebangkitan teknologi ini sangat berpengaruh sekali terhadap sikap dan sifat dari masyarakat. Pengaruh tersebut membuat kebutuhan dasar manusia juga berubah secara fungsional. Salah satu kebutuhan manusia adalah belajar, cara belajar yang sudah berbeda dengan dengan generasi yang sebelumnya. Belajar pada era millenial ini sudah menggunakan teknologi yang canggih dan tidak monoton. Sistem penyampaian ilmu yang diberikan mulai lebih menarik dan lebih mudah untuk dipahami oleh generasi milenial. Metode yang digunakan dalam proyek ini adalah metafora konsep artificial body manufacture, dimana mengantikan body manusia dengan teknologi atau robot yang di aplikasikan di dalam perancangan bangunan proyek. Salah satu ilmu pengetahuan yang menarik untuk penggunaan teknologi ini adalah life \& sciences, tentang tubuh dan teknologi manusia. Menciptakan sebuah edukasi yang menyenangkan yang berbasiskan sistem dan teknologi yang canggih serta mengenalkan kepada masyarakan tentang ilmu pengetahuan sains yang baru dan modern. Edutainment merupakan tempat yang di desain secara canggih, serta memberikan suasana seperti belajar untuk masa depan.
\end{abstract}

Kata kunci: Edutainment; Future; Milenial; Tubuh; Teknologi

\begin{abstract}
Millennial generation born in the era of technological revival is very influential on the attitude and nature of society. These influences make basic human needs also change functionally. One human need is learning, a way of learning that is different from the previous generation. Learning in this millennial era has used sophisticated and not monotonous technology. The system of delivering knowledge is starting to be more interesting and easier to understand by the millennial generation. The method used in this project is the metaphor of the concept of artificial body manufacture, which replaces the human body with technology or robots that are applied in the design of project buildings. One interesting science for the use of this technology is life \& sciences, about the body and human technology. Creating a fun education based on sophisticated systems and technology and introducing people to new and modern science. Edutainment is a place that is sophisticatedly designed, and provides an atmosphere like learning for the future.
\end{abstract}

Keywords: Body; Edutainment; Future; Technology; Millennial

\section{PENDAHULUAN}

Generasi Milenial atau yang beberapa orang menyebutnya Generasi Y sebagian besar dianggap sebagai sekelompok orang yang lahir antara tahun 1980-2000. Generasi milenium telah menjadi dewasa selama masa perubahan teknologi, globalisasi, dan gangguan ekonomi. Itu memberi mereka serangkaian perilaku dan pengalaman yang berbeda dari orang tua mereka. "Generasi Millenial tidak seperti generasi muda lainnya. Mereka lebih banyak, lebih kaya, lebih berpendidikan, dan lebih beragam secara etnis. Lebih penting lagi, mereka mulai memanifestasikan beragam kebiasaan sosial positif yang tidak lagi diasosiasikan dengan orang tua dengan kaum muda, termasuk fokus baru pada kerja tim, prestasi, kesederhanaan, dan perilaku yang baik."- Neil Howe dan William Strauss

Perkembangan teknologi yang sangat pesat ini sangat berpengaruh pada berbagai bidang kehidupan manusia millennial. Pada akhirnya memunculkan inovasi- inovasi yang unik dan baru pada bidang IT, pendidikan, mileter, perdagangan, dan otomotif. Perkembangan teknologi 
tersebut untuk mempermudah kegiatan yang di lakukan, salah satunya dalam belajar, dimana belajar merupakan sesuatu kebutukan manusia yang dasar. Pengetahuan yang populer dan berkembang pada era milenial ini salah satunya dari bidang life \& Sciences, di detailkan menjadi pelajaran sains tubuh dan teknologi. Pengetahuan baru ini akan sangan berpengaruh terhadap pendidikan dan perekonomian kedepannya.

Belajar adalah perubahan yang relatif permanen dalam perilaku atau potensi perilaku sebagai hasil dari pengalaman atau latihan yang diperkuat. Belajar merupakan akibat adanya interaksi antara stimulus dan respon. Seseorang dianggap telah belajar sesuatu jika dia dapat menunjukkan perubahan perilakunya. Menurut teori ini, dalam belajar yang penting adalah input yang berupa stimulus dan output yang berupa respons. Pada masa millennial ini belajar formal sudah sangat kuno dan lambat, era digitalisasi ini mendorong perkembangan pendidikan menjadi lebih maju dan berbasis teknologi canggih. Melalui teknologi pembelajaran para pendidik akan mudah melakukan simulasi pembelajaran mendekati kondisi nyata dari suatu materi pembelajaran yang abstrak

\section{KAJIAN LITERATUR}

\section{Generasi Milenial}

Generasi Milenial atau yang beberapa orang menyebutnya Generasi $Y$ sebagian besar dianggap sebagai sekelompok orang yang lahir antara tahun 1980-2000. Generasi milenium telah menjadi dewasa selama masa perubahan teknologi, globalisasi, dan gangguan ekonomi. Itu memberi mereka serangkaian perilaku dan pengalaman yang berbeda dari orang tua mereka. Mereka juga generasi pertama dari penduduk asli digital, dan ketertarikan mereka terhadap teknologi membantu membentuk cara mereka hidup. Akhirnya, mereka didedikasikan untuk kesehatan, mencurahkan waktu dan uang untuk berolahraga dan makan dengan benar. Gaya hidup aktif mereka memengaruhi tren dalam segala hal mulai dari makanan dan minuman hingga desain rumah. Zaman media sosial, video game, dan kehidupan virtual membuka pikiran dan desain generasi baru arsitek yang menciptakan pilihan desain saat ini. Daripada belajar melalui metode yang lebih tradisional, masyarakat millennial terinspirasi oleh apa yang telah mereka lihat di desktop, ponsel, dan tablet mereka. Para pemimpin industri percaya bahwa generasi yang dikenal akan ekspresi diri dan kesadaran sosial ditakdirkan untuk mengubah masa depan lapangan pekerjaan yang baru.

\section{Belajar}

Definisi belajar dapat juga diartikan sebagai segala aktivitas psikis yang dilakukan oleh setiap individu sehingga tingkah lakunya berbeda antara sebelum dan sesudah belajar. Perubahan tingkah laku atau tanggapan karena adanya pengalaman baru, memiliki kepandaian/ ilmu setelah belajar, dan aktivitas berlatih. Perkembangan belajar:

Belajar dulu/ konvensional

- Belajar konvensional berarti beajar yang menggunakan tenaga kerja seperti pembimbing/ guru dalam proses belajrnya.

- Belajar konvensional juga harus di lakukan secara bertatap muka sehingga maksud dan tujuan yang di sampaikan oleh pembimbing dapat tersalurkan dengan baik.

- Belajar konvensional dalam pelajarannya yang disampaikan, media buku dan gambar menjadi salah satu teknik penyampainnya.

- Belajar konvensional juga berarti memiliki batas waktu dan jadwal dengan pembimbing yang menjadi fasilitatornya dalam belajar.

Belajar sekarang

- Konstruktif, siswa dapat menggabungkan ide-ide baru ke dalam pengetahuan yang telah dimiliki sebelumnya.

- Kolaboratif, siswa dalam suatu kelompok dapat bekerjasama, berbagi ide, saran atau pengalaman, menasehati, dan memberi masukan untuk kelompoknya.

- Kontekstual, proses belajar yang bermakna (real-world) melalui pendekatan problem-based 
atau case-based learning.

- Reflektif, siswa dapat menyadari apa yang telah ia pelajari serta merenungkan apa yang telah dipelajarinya sebagai bagian dari proses belajar itu sendiri.

- Multisensory, pembelajaran dapat disampaikan untuk berbagai modalitas belajar (multisensory), baik audio, visual maupun kinestetik.

\section{Teknologi Digital}

Teknologi komunikasi digital adalah teknologi yang berbasis sinyal elektrik komputer, sinyalnya bersifat terputus-putus dan menggunakan sistem bilangan biner. Bilangan biner tersebut akan membentuk kode-kode yang merepresentasikan suatu informasi tertentu. Setelah melalui proses digitalisasi informasi yang masuk akan berubah menjadi serangkaian bilangan biner yang membentuk informasi dalam wujud kode digital. Kode digital tersebut nantinya akan mampu dimanipulasi oleh komputer. Contohnya adalah gambar kamera video yang telah diubah menjadi bentuk digital. Bentuk digital tersebut mewakili element gambar (pixel). Elemen gambar tersebut dapat dimanipulasi oleh komputer. Sehingga kita dapat menciptakan efek tertentu pada gambar serta dapat juga memperbaiki kualitas gambar yang dianggap kurang baik. Bentuk manipulasinya bisa berupa penambahan intensitas cahaya pada gambar, sehingga gambar yang ada menjadi lebih terang atau gelap, meningkatkan ketajaman gambar yang kurang fokus, serta memperbaiki warna pada bagian tertentu dari gambar.

\section{Jenis Teknologi Digital}

Menurut buku THE NEXT 50 YEARS yang di tulis oleh Richard Watson, dalam sub bab tentang kebangkitan teknologi, menyebutkan bahwa akan banyak perangkat penunjang kemajuan teknologi yang akan mempengaruhi perkembangan ilmu pengetahuan baru. Berikut merupakan perangkat teknologi tersebut:

- Artificial Intelligence/Al

Artificial Intelligence atau Al acap juga disebut sebagai machine learning. Dalam konsep Al intinya kita memasok ribuan data dan clue kepada mesin komputasi. Nantinya mesin ini akan berpikir sendiri based on input yang kita berikan tersebut. Jadi kelak yang akan proses seleksi karyawan Google adalah articial intelligence, bukan lagi manusia. Proses interview dilakukan dengan robot artificial intelligence, yang dengan presisi akan bisa memprediksi mana calon kandidat yang bagus dan mana yang abal-abal. Teknologi BIG DATA memungkinkan terjadinya Al. Sebuah machine learning yang punya kapasitas mengolah milyaran data (big data) pelan-pelan akan bisa mikir sendiri, tanpa campur tangan manusia lagi.

- Internet of Things

Internet of things atau loT pada dasarnya adalah seperangkat appliance yang bisa saling terkoneksi dengan sensor dan internet. Dan kemudian bisa Anda kendalikan via smartphone Anda. dengan jumlah yang sesuai kebutuhan. IoT tahu berapa kebutuhan yang pas bagi Anda. Jika ada potensi kerusakan maka segera secara otomatis sensor akan terhubung dengan aplikasi spare parts untk melakukan order penggantian spare parts.Inilah yang disebut sebagai Industrial internet. Yakni saat semua proses pemeliharaan mesin-mesin di pabrik berjalan secara otomatis via Internet of Things. Bayangkan betapa efisien dan cepatnya proses pemeliharaan ribuan mesin di pabrik.

- $\quad V R \& A R$

VR (Virtual Reality)

Teknologi yang memungkinkan user dapat berinteraksi dengan suatu lingkungan berdimensi 3 yang disimulasikan oleh komputer terhadap suatu objek nyata atau imajinasi, sehingga membuat user seolah-olah terlibat secara fisik pada lingkungan tersebut.

AR (Augmented Reality)

Teknologi yang menggabungkan benda-benda maya (baik berdimensi 2 dan/atau berdimensi 3) dan benda-benda nyata ke dalam sebuah lingkungan nyata berdimensi 3, lalu memproyeksikan benda-benda maya tersebut dalam waktu nyata agar terintegrasi dan 
berjalan secara interaktif dalam dunia nyata

- E-learning

E-Learning adalah pembelajaran yang disusun ialah dengan tujuan menggunakan suatu sistem elektronik atau juga komputer sehingga mampu untuk mendukung suatu proses pembelajaran.

\section{Faktor Keterlambatan Indonesia di Bidang Teknologi}

- Dana yang tidak sedikit untuk melakukan research dan pengembangan lebih lanjut sebuah teknologi.

- Keminiman ahli teknologi di Indonesia, membuat Indonesia tidak ada reasearh ataupun pengembangan ilmu pengetahuan lebih lanjut.

- Masyarakat cenderung hanya menjadi konsumen dari hasil research negara- negara lain, yang membuat kita malas untuk menemukan sesuatu yang lebih baru.

- Moderenisasi teknologi digital Indonesia yang sangan kurang, dimana konvensional masih sangat melekat pada masyarakat Indonesia sendiri.

\section{METODE}

Menggunakan metode deskriptif analisis dalam merancang desain bangunan, dari program sampai dengan studi - studi ruang baru yang sesuai dengan tema future. Metode ini mendeskriptifkan keterhubungan antara milenial dan teknologi yang mempengaruhi kebutuhan dasar manusia, salah satunya adalah belajar. Sehingga tercipta faktor kegiatan belajar baru yaitu, edutainment. Belajar pada milenial sudah berubah akibat faktor teknologi dan sifatnya, sehingga tercipta suatu belajar baru yaitu, edutainment. Edutainment disini mengajarkan atau menginformasikan sebuah pengetahuan baru yang sangat menarik yaitu life \& sciences. Ilmu pengetahuan ini juga di pecah kembali menjadi lebih khusus yang di dalami dalam proyek ini, yaitu body and technology.

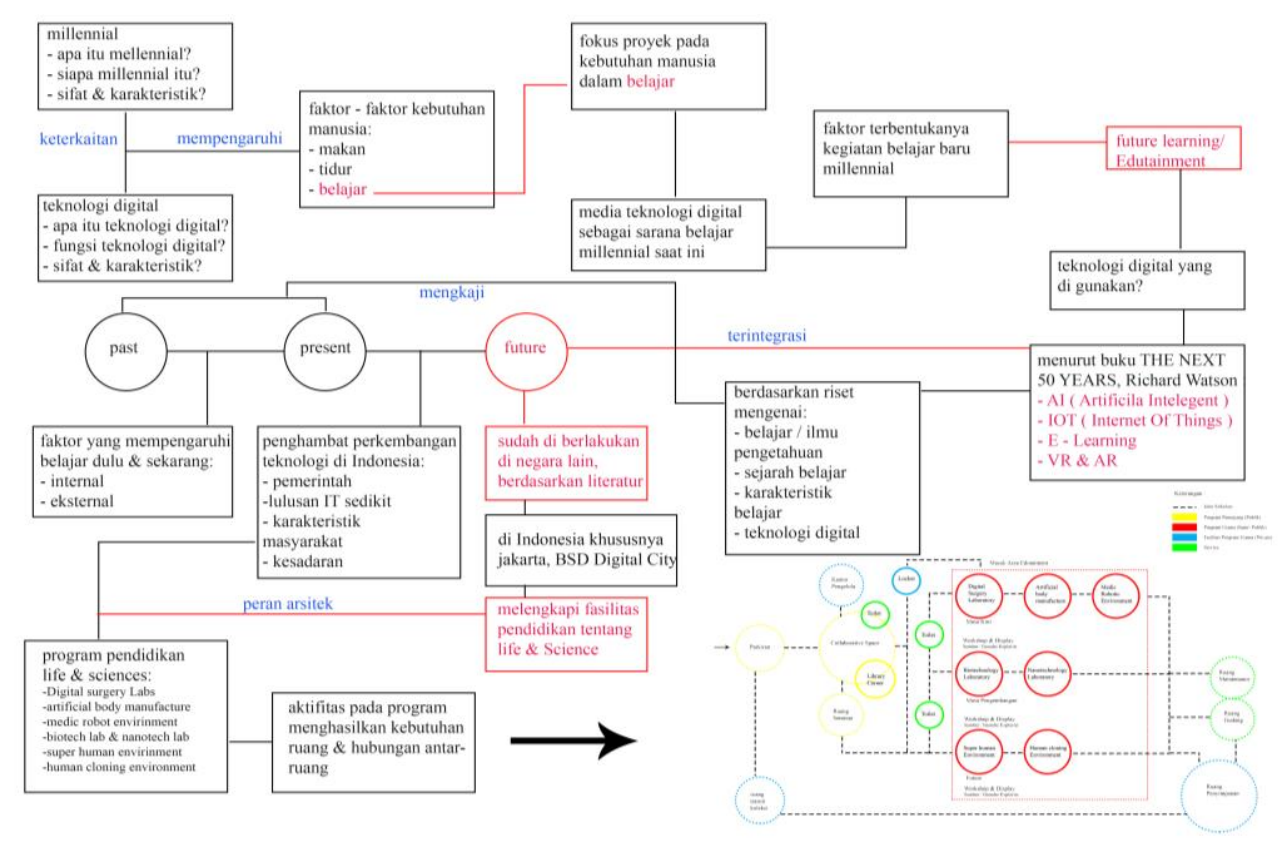

Gambar 1. Kerangka Konsep

Sumber: Penulis, 2019

Dari pengurain konsep tersebut, menghasilkan sebuah program- program baru yang unik dan belum pernah ada di Indonesia. Program - program ini di susun dan di hubungkan dengan program penunjang lainnya, sehingga terbentuklah hubungan antar ruang dari proyek ini. 
Program penunjang pada proyek ini jjuga bersifat milenial dan juga sangat berpengaruh terhadap teknologi canggih.

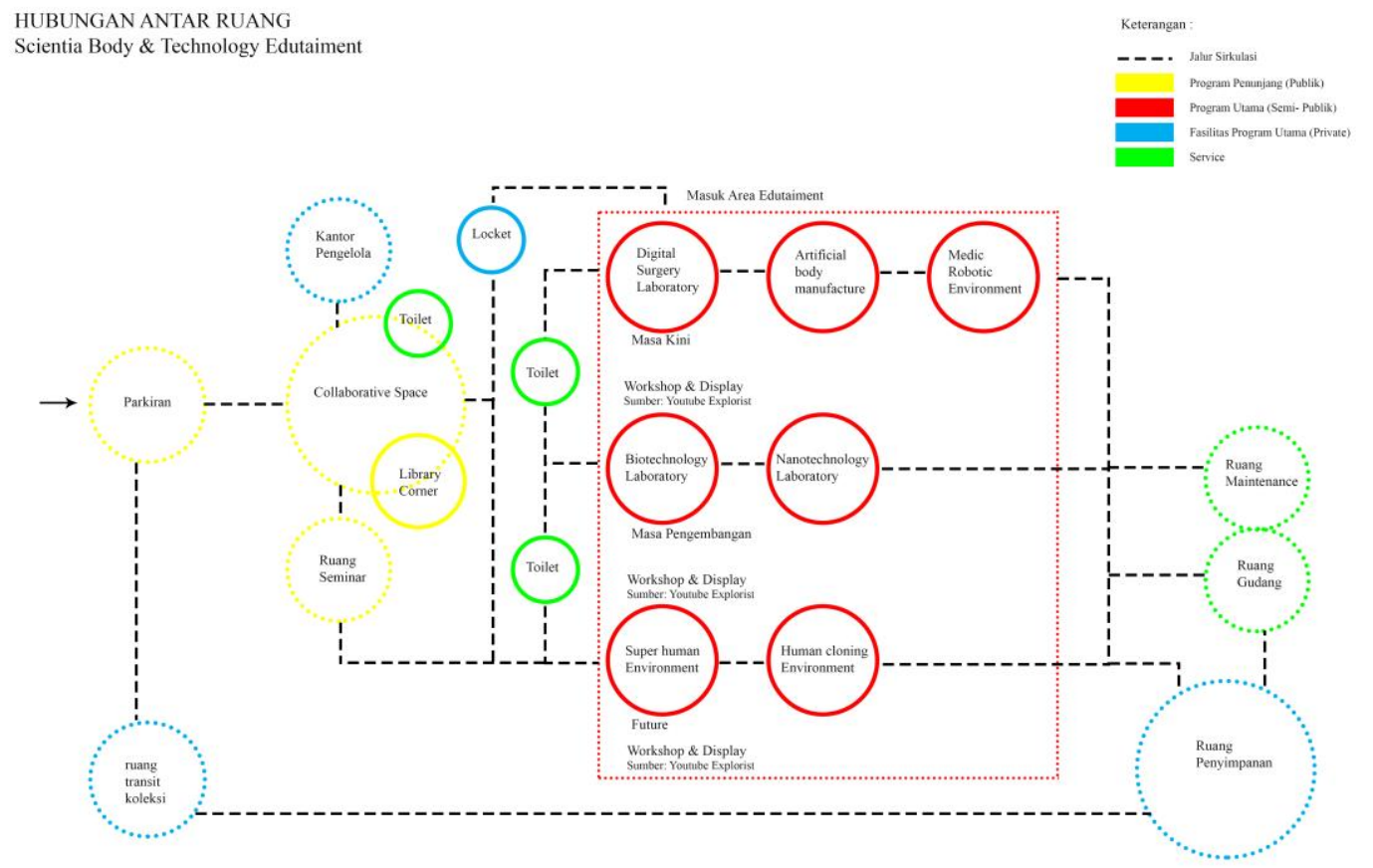

Gambar 2. Hubungan Antar Ruang

Sumber: Penulis, 2019

a. Tahap pengumpulan data

b. Pengumpulan data dilakukan dengan cara:

- Melakukan survey lapangan dan observasi

- Melakukan studi pustaka

- Melakukan studi literatur pada proyek sejenis

c. Tahap analisa

d. Metode yang dilakukan dalam melakukan analisa adalah:

- Induksi, yaitu menarik kesimpulan dari fakta yang ada

- Komparasi, yaitu menganalisis melalui data yang sudah di kumpulkan melalui survei dan studi literatur

e. Tahap sintesis

f. Tahap ini merupakan tahap perumusan konsep, dari hasil analisa

\section{DISKUSI DAN HASIL}

\section{Pengenalan dan Analisa Kawasan}

Analisis tapak yang akan dipilih diawali dengan peninjauan langsung. Yaitu dengan survei pada daerah kawasan Gading Serpong. Dari analisis tapak dengan mengunjungi langsung ke tapak, dilakukan dengan pengamatan lingkungan dan lalu lintas sekitar, sehingga proses sintesa berjalan secara parallel dengan proses desain. Dengan posisi tapak yang menghadap ke arah timur, menjadi sebuah keunggulan bagi desain karena bisa menggunakan fasad terbuka karena suhu matahari yang masuk kedalam bangunan tidak panas. Lokasi tapk juga berada pada jalan utama yang aksesnya bisa langsung ke arah toll Jakarta - Merak. 


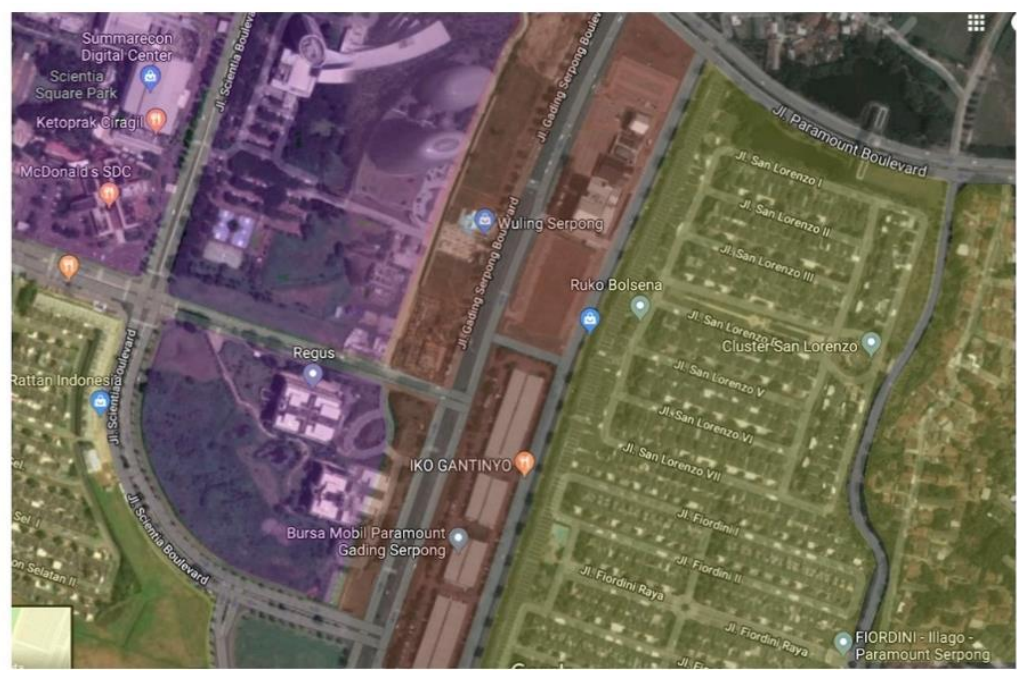

Gambar 3. Lokasi Tapak

Sumber: Penulis, 2019

Fasad

Fasad pada bangunan menggunakan 2 material yang berbeda yaitu fasad beton dan kaca, untuk menghasilkan desain yang deskontruksi. Pemilihan material juga berdasarkan konsep gubahan massa, bagian yang lancip pada bangunan menggambarkan pengganti part tubuh yang rusak. Penerapan metode ini menggambarkan artificial body manufacture. Penggunaan kaca di setiap sisi bangunan berguna untuk memasukan cahaya kedalam bangunan, dikarenakan tanah kavling yang tidak berjarak bisa menyebabkan kekurangan cahaya alami pada bangunan. Penggunaan material beton adalah untuk memberikan kesan bangunan yang industrial, serta beton merupakan bahan yang tahan terhadap suhu luar, suhu di ruangan juga terjaga. Pada fasad beton terdapat garis- garis kaca yang memotong, garis tersebut menggambar link- link server yang terdapat pada komputer atau teknologi digital, sehingga menciptakan fasad yang terkesan bangunan masa depan.

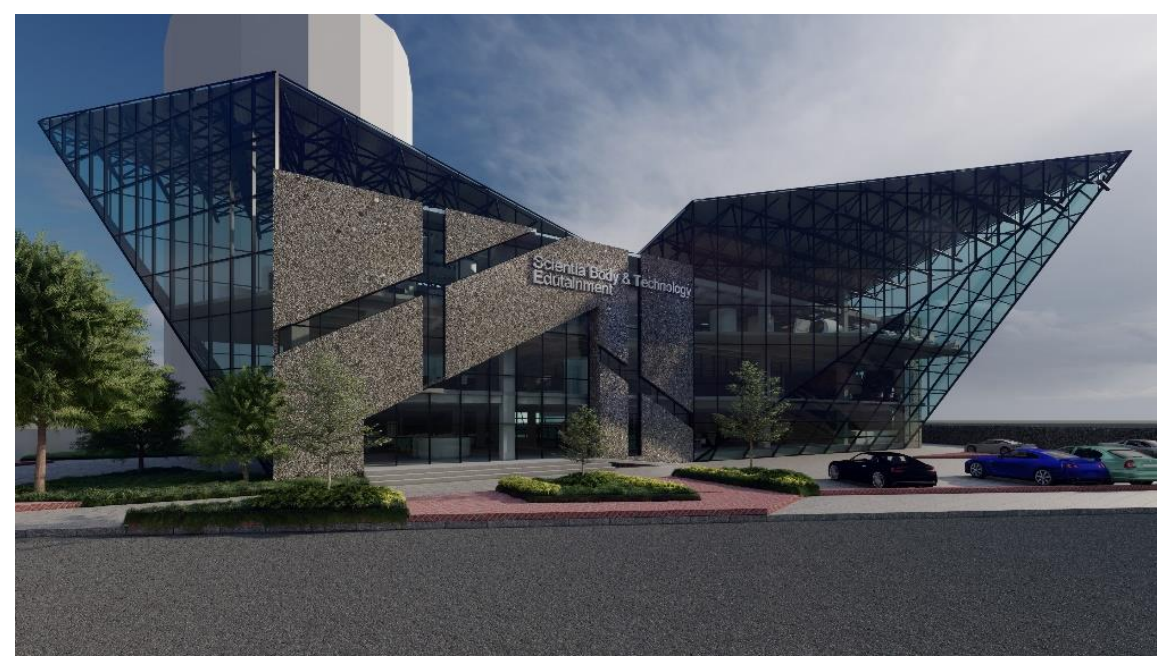

Gambar 4. Eksterior Bangunan

Sumber: Penulis, 2019

\section{Denah dan Pembagaian Ruang}

Suasana dalam bangunan yang di ciptakan begitu modern dan penuh dengan teknologi canggih untuk mengenalkan masyarakat baru tentang modern science serta teknologi canggih pendukungnya. Bangunan ini juga terdapat program penunjang yaitu collaborative space dan café resto, Program lainnya yang berupa teknis seperti ME dan ruang kantor. 


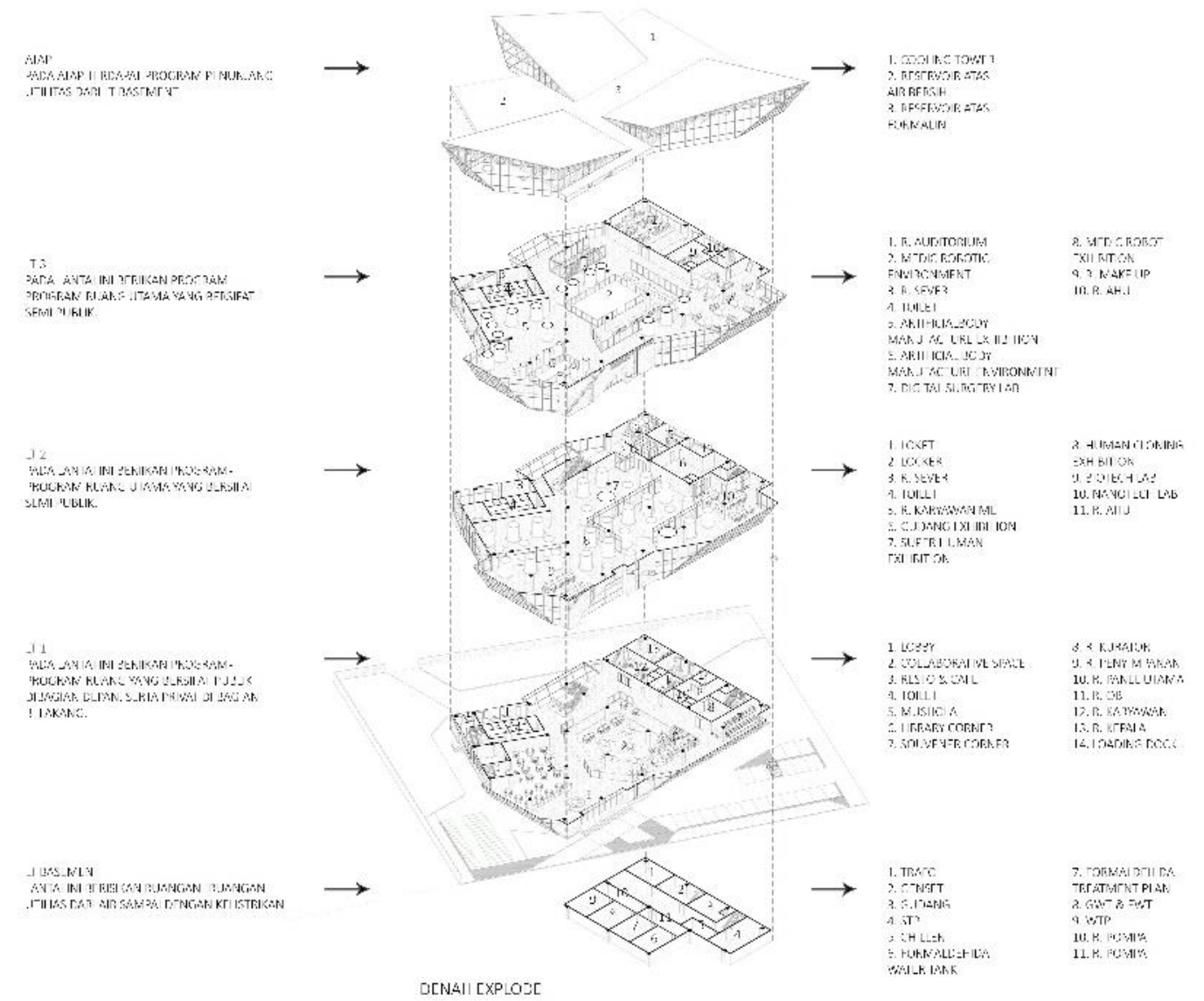

Gambar 5. Denah Explode

Sumber: Penulis, 2019

Pada lantai dasar bangunan berisikan program- program penunjang, seperti collaborative space dan resto café. Tidak ada batas fisik pada collaborative space untuk menciptakan kesan yang terbuka bagi siapapun, dan ketidakterbatasan ruang. Resto dan café di lantai bawah sebagai penambahan fungsi komersial pada bangunan. Pada lantai dasar juga di lengkapi kantor pengelola serta area servis yang di letakan pada bagian belakang, untuk memberikan privasi pada fungsi program tersebut.

Pada lantai dua bangunan berisikan program utama proyek, penempatan program pada lantai dua untuk membedakan fungsi yaitu semi - publik. Pengunjung harus melewati loket dan ruang ganti sebelum memasuki area edutainment. Sistem yang di berikan pada program ini adalah one way, sehingga pengunjung tidak kesulitan dalam mengambil barang yang di titipkan di ruang ganti. Area edutainment pada lantai 2 berisikan pameran- pameran teknologi super human dan human cloning. Terdapat ruang server juga pada bangunan ini untuk mengatur sistem pada lantai ini.

Pada lantai tiga juga berisikan program utama bangunan, program yang di berikan pada area edutainment ini berupa area praktek penggunaan teknologi tersebut seperti artificial body manufacture, digital surgery labs, dan medic robotic. Pada lantai ini juga terdapat ruang auditorium dan ruang server untuk mengatur dan menjalankan fitur canggih. Pada lantai basement pada bangunan ini berisikan ruang- ruang servis serta ruang teknis lainnya yang berhubungan dengan mekanikal, elektrikal, dan plumbing untuk menjalankan sistem teknis pada bangunan. 


\section{KESIMPULAN DAN SARAN}

Generasi milenial adalah masyarakat terbesar yang lahir di dunia, dimana teknologi berkembang sangat pesat dan sedang dalam puncaknya khususnya teknologi digital. Teknologi ini akan menjadi salah satu faktor yang mempengaruhi kebutuhan manusia, salah satunya adalah belajar. Peningkatan Teknologi dalam bidang pendidikan ini sangat mendukung program pemerintah dalam pemerataan pendidikan di seluruh Indonesia, dengan tujuan untuk mempersiapkan masyarakat millennial ini bertahan dalam ekonomi global.

Berdasarkan analisis Gading Serpong merupakan Kawasan untuk kelompok generasi milenial, kawasan tersebut menyediakan fasilitas penunjang kebutuhan utama berupa perumahan, kantor, sekolah, dan taman. Kawasan ini juga di lengkapi dengan akses tol outeringroad yang dekat dan mudah. Kawasan ini menjadi pusat bagi para masyarakat Millennial berkumpul dan berinteraksi. Proyek yang diusulkan adalah " Pusat Edukasi Sains Tubuh \& Teknologi" dimana proyek akan menjadi wadah pendidikan yang baru dan lebih modern yang di lengkapi dengan teknologi- teknologi digital. Proyek ini dibangun untuk mendukung program pemerintah dalam pemerataan pendidikan di Indonesia. Proyek ini menawarkan pengetahuan baru yang berbasis teknologi yang akan menjadi pekerjaan masa depan, sehingga mempersiapkan masyarakat milenial untuk menghadapi perubahan tersebut.

\section{REFERENSI}

Agung , L. (2018, desember 20). Pekerjaan di Masa Depan: Apa yang Dimiliki Manusia dan Tidak Dimiliki Robot Digtal?

https://ekonomi.kompas.com/read/2018/12/20/060300626/pekerjaan-di-masa-depan-apa-yang-dimiliki-manusia-dan-tidak-dimiliki-robot?page $=1$.

Antariksa, Y. (2018, juli 9). 5 Teknologi Masa Depan Yang Akan Mengubah Wajah Digital Anda.strategimanajemen.net/2018/07/09/5-teknologi-masa-depan-yang-akanmenentukan-wajah-kehidupan-digital-anda/

BBC (2019, januari 16).7 Profesi Yang Terancam Dimasa. www.bbc.com/indonesia/majalah46760409

Ermadi, A. (2018, november 3). 10 Teknologi Kesehatan Masa Depan www.digination.id/read/012137/10-teknologi-kesehatan-masa-depan

Fourhooks (2015, April 26). The Generation Guide - Millennials, Gen X, Y, Z and Baby Boomers fourhooks.com/marketing/the-generation-guide-millennials-gen-x-y-z-and-baby-boomersart5910718593/

Gani, A. (2018). Masa Depan Teknologi Di dunia pekerjaan manusia www.hipwee.com/opini/masa-depan-teknologi-di-dunia-pekerjaan-manusia/

James, C. (2010). Extreme future.

Linguamarina (2018, desember 2 ). 23 Jobs Of the Future www.youtube.com/watch?v=we7zHcsgo0o

Kompas (2009). serpong kota baru yang gemerlap dan mengikat. interaktif.kompas.id/serpong Lopez, N. (2017, April 1). Gen Y: Millennials in Architecture. Retrieved from https://medium.com/studiotmd/gen-y-millennials-in-architecture-476e9839321b

Motherly. (2019). 5 way Millenials are Changing Parenting Forever www.mother.ly/parenting/5-ways-millennials-are-changing-parenting-forever

Nielsen. (2017). millennials on millennial : A Look At Viewing Behavior, Distraction And Social Media Stars www.nielsen.com/us/en/insights/news/2017/millennials-on-millennials-a-look-at-viewingbehavior-distraction-social-media-stars.html

Peraturan Daerah Tangerang. (2013). Kabupaten Tangerang.

Richard W. (2009). The next 50 years.

United Nations Department of Economic and Social Affairs. (2018). Sustainable Development Goals. https://sustainabledevelopment.un.org/sdg4 
VPLI. (2018). Education Friendly Imapact of Digital Library. vpli.org/5-education-friendly-impactof-digital-library/. 
